\title{
根尾断層周辺に発生する 極微小地震の観測
}

$\begin{array}{cllll}\text { 京都大学理学部 } & \text { 三 } & \text { 木 } & \text { 晴 } & \text { 男 } \\ \text { 阿山地震観测所 } & \text { 三 } & & & \\ \text { 同 } & \text { 渡 } & \text { 辺 } & & \text { 晃 } \\ \text { 同 } & \text { 島 } & \text { 由 } & \text { 充 } & \text { 彦 }\end{array}$

(昭和 40 年 6 月 27 日受理)

\section{Observations of Ultra Microearthquakes in the Vicinity of Neo Valley Fault in Central Honshu, Japan.}

\author{
Haruo Miki, Hikaru Watanabe, Mitsuhiko Shimada \\ Abuyama Seismological Observatory, Faculty of Science, Kyoto University \\ (Received June 27, 1965)
}

On August 1963, the observations of ultra microearthquakes were carried out by the Research Group for Ultra Microearthquakes. One of the main purposes of these observations was to elucidate the seismic activity of microearthquakes occurring in Chubu and Kinki Districts, especially in the vicinity of Neo Valley Fault in Central Honshu, Japan. Most of these observations were made by use of velocity seismographs with high magnification (about $10^{6} \sim 10^{7} \mathrm{~mm} /$ kine at short period less than $1 \mathrm{sec}$.) in order to register very small earthquakes of seismic magnitudes less than zero and to get a good noise-to-signal ratio at the short period.

During the observation period, about 1,500 earthquakes were observed by our Group at temporary stations, 9 in total, and also at 4 routine stations of Kyoto and Gifu Universities, spread widely over Kinki and Chubu Districts up to distance of about $170 \mathrm{~km}$. As the result of the observations, we could find that about 50 earthquakes, including microearthquakes of $\mathrm{M}$ less than 2 or 3 , were occurring every day in this region. This fact shows that the seismicity of a given region of high activity can be estimated from high-gain recordings during a very short time interval.

\section{§1. まえがき}

1963 年 7 月 25 日から 8 月 31 日に亘つて, 極微小地震研究グループの第 1 回目の共同 観測が，岐阜県根尾谷をかこえで行なわれた。この共同観測では根尾断層附近に発生すると予 想される極微小地震を小規模な観測網で記録すると同時に，さらにその周囲を大規模な観測網 でとりかこみ，近畿および中部地方の広い範囲にわたつて発生する微小地震の 観測を行なつ た。

昭和 39 年 5 月 7 日地震学会で発表. 
この共同観測によつて観測された地震は験震表にまとめて別に発表してあるので，ここでは これから得られた結果の概要を報告するにとどめ, さらに詳細な研究は他の論文にゆずりた い.

\section{§ 2. 観測の概要}

この共同観測に参加した各機関，観測点の位置および観測期間を一括して Table 1 および Fig. 1 に示す. このうち根尾谷周辺の 5 観測点 (Neo Valley network と呼ぶことにする.) は，神所を中心にして， $5 \sim 7 \mathrm{~km}$ の間隔で配置され，マグニチュード 0 以下の極微小地震の 観測に主目標を和き，特に刻時精度および記録装置の感度の向上をはかつた。このような高感

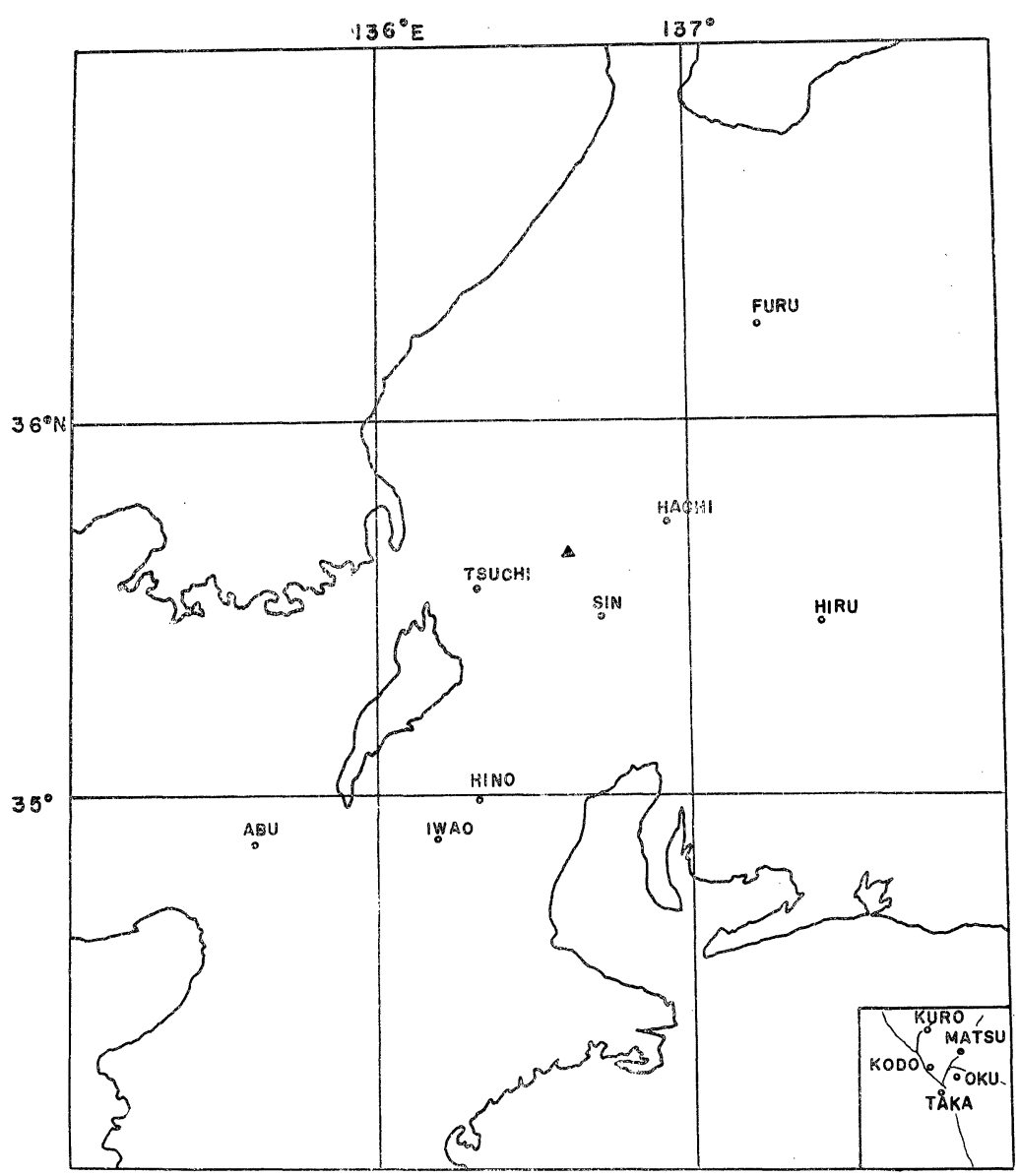

Fig. 1. Distribution of observation stations. The triangle corresponds to the location of Neo Valley network which is given in lower right corner of the figure. 
度観測では back ground noise とのかねあいで，観測点の位置および感度が左右されるの で， あらかじめ，短周期常時微動が 10〜20 $\mu$ kine 以下になる場所を選び観測点を決めた. さらにこの $\mathrm{S} / \mathrm{N}$ 比を向上させるため, 夜間の静隠時を選び (21 時〜04 時)，約 7 時間の連続 観測を行なうことにした。

Table 1. List of temporary and routine stations, observation periods and observers.

\begin{tabular}{|c|c|c|c|c|c|}
\hline $\begin{array}{l}\text { Observation } \\
\text { station }\end{array}$ & Latitude (N) & Longitude (E) & $\begin{array}{l}\text { Altitude } \\
(\mathrm{m})\end{array}$ & $\begin{array}{l}\text { Observation } \\
\text { period }\end{array}$ & Observers \\
\hline Abuyama & $34^{\circ} 51^{\prime} 24.4^{\prime \prime}$ & $135^{\circ} 34^{\prime} 22.4^{\prime \prime}$ & 215 & routine & $\begin{array}{l}\text { Abuyama seismological } \\
\text { Obs., Kyoto Univ. }\end{array}$ \\
\hline Hino & 345909.0 & 1361647.0 & 260 & 24 July $\sim 28$ Aug. & Ditto \\
\hline Iwao & 345257.0 & 1360756.0 & 400 & 20 July $\sim 28$ Aug. & Ditto \\
\hline Tsuchikura & 353530.3 & 1361816.1 & 340 & 25 July 29 Aug. & $\begin{array}{l}\text { Geophysical Inst., } \\
\text { Kyoto Univ. }\end{array}$ \\
\hline Sinpukuji & $\begin{array}{lll}35 & 27 & 16.2\end{array}$ & $136 \quad 4735.7$ & 50 & routine & Gifu Univ. \\
\hline Hirukawa & 353114.0 & 1372146.0 & 360 & routine & Ditto \\
\hline Furukawa & $\begin{array}{lll}36 & 12 & 23.0\end{array}$ & 1370858.0 & 670 & routine & Ditto \\
\hline Hachiman & $\begin{array}{lll}35 & 45 & 22.0\end{array}$ & 1365821.0 & 264 & 29 July 29 Aug. & $\begin{array}{l}\text { Earth. Res. Inst., } \\
\text { Tokyo Univ. }\end{array}$ \\
\hline Kurozu & 354124.0 & 1363547.0 & 370 & 15 Aug. 28 Aug. & $\begin{array}{c}\text { Geophysical Inst., } \\
\text { Tôhoku Univ. }\end{array}$ \\
\hline Matsuda & 353929.0 & 1363924.0 & 292 & 15 Aug. $\sim 28$ Aug. & $\begin{array}{l}\text { Geophysical Inst., } \\
\text { Tokyo Univ. }\end{array}$ \\
\hline Kôdoko & 353810.0 & 1363629.0 & 265 & 29 July 28 Aug. & $\begin{array}{l}\text { Earth. Res. Inst., } \\
\text { Tokyo Univ. }\end{array}$ \\
\hline Okutani & $3537 \quad 19.4$ & 1363913.2 & 260 & 13 Aug. 28 Aug. & $\begin{array}{c}\text { Inst. of Earth Science, } \\
\text { Nagoya Univ. }\end{array}$ \\
\hline Takao & 353549.0 & 1363742.0 & 180 & 12 Aug. 28 Aug. & $\begin{array}{l}\text { Abuyama seismological } \\
\text { Obs., Kyoto Univ. }\end{array}$ \\
\hline
\end{tabular}

一方，大規模な観測網 (large network と呼ぶことにする.) は，京都大学，岐皁大学の 既設の観測所を含め，約 $20 \mathrm{~km}$ 間隔のネットを作り，24 時間の連続観測を行なつた.

各観測点の位置は三角測量にもとづく方法で決定した. 二三の既設観測所を除き，大部分の 観測点では, 固有周波数 $3 \mathrm{cps}$ の地震計を使い，乙れを増幅器に接続し，電磁オッシログラ フまたは磁気テープに記録した。刻時装置はJJY または NHK のラジオシグナルで較正さ れ，Neo Valley network および large network ではそれぞれ 1/100 秒および 1/10 秒 の精度を保つた。

地震計および記録装置の感度は各観測点により，また back ground noise により一定し 
ていないが, Neo Valley network では 10 100 cps でほぼ一定感度をもつ速度地震計学使 用し，艺の最高感度はほ添 $10^{6} \sim 10^{7} \mathrm{~mm} /$ kine である。

\section{§3。地震 記 象}

観測期間中に記録された地震の総数は 1489 個であつた。これらの地震の読取りほ各観測者

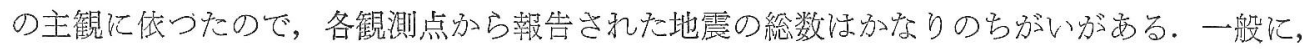

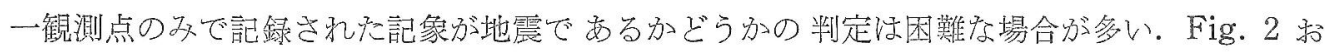
よびFig. 3 核属で記録され，他の隣接した観测点で忹記録されなかつたものの例である。 Fig.2の記象にみられるように，比校的明膫に P 波沶よび S 波が記録され，これは一見し

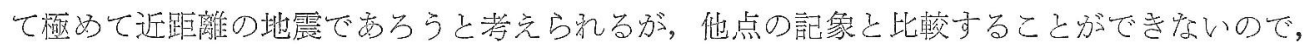
自然地震であるかどうかの判定がもずかしい。さらに Fig. 3 の記象怔震動継続時間分 0.3 秒

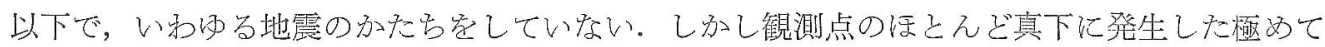

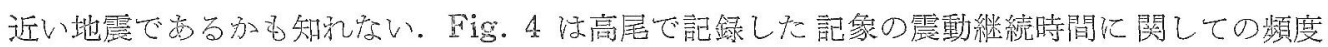

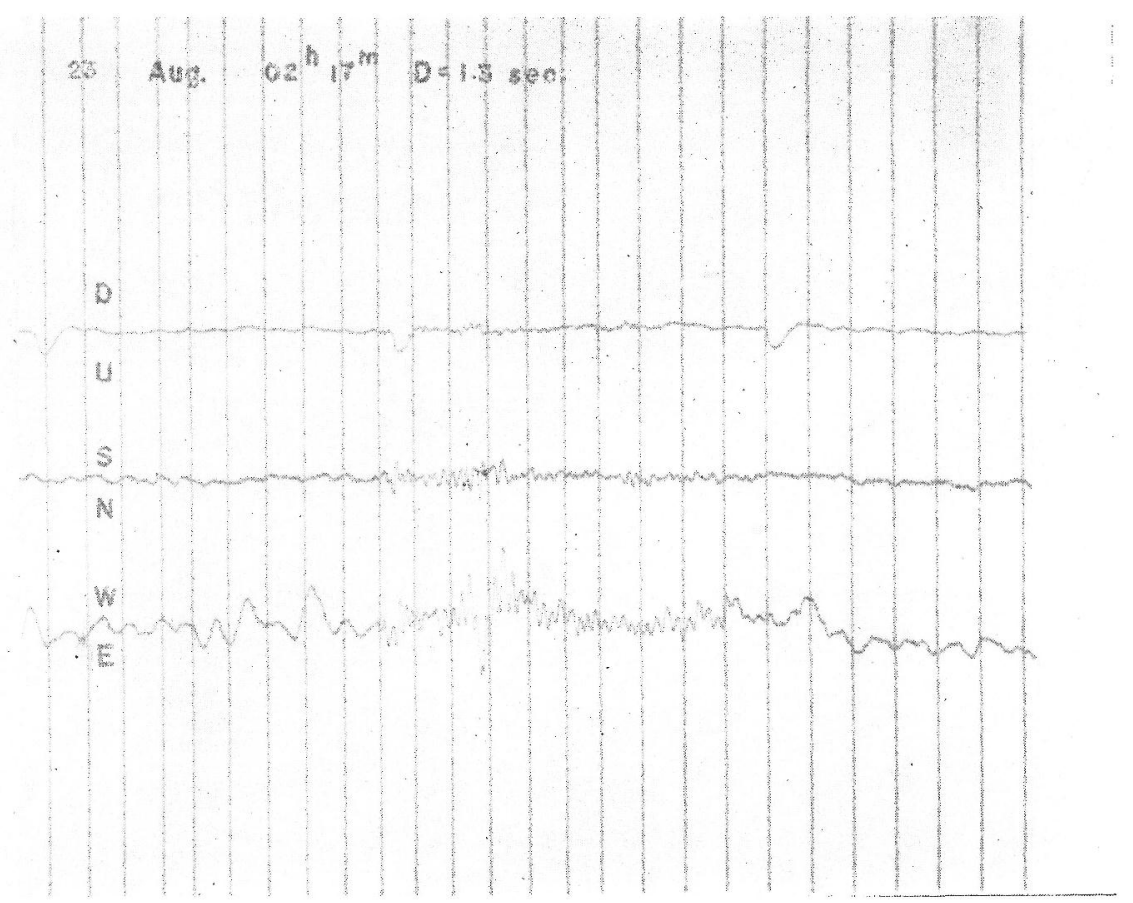

Fig. 2. An example of seismograms recorded at Takao station.

The $\mathrm{P}$ and $\mathrm{S}$ waves are clearly recorded so that these traces should not be rejected merely because they are not registered at the other stations.

(Time marks: every $0.1 \mathrm{sec}$ ) 


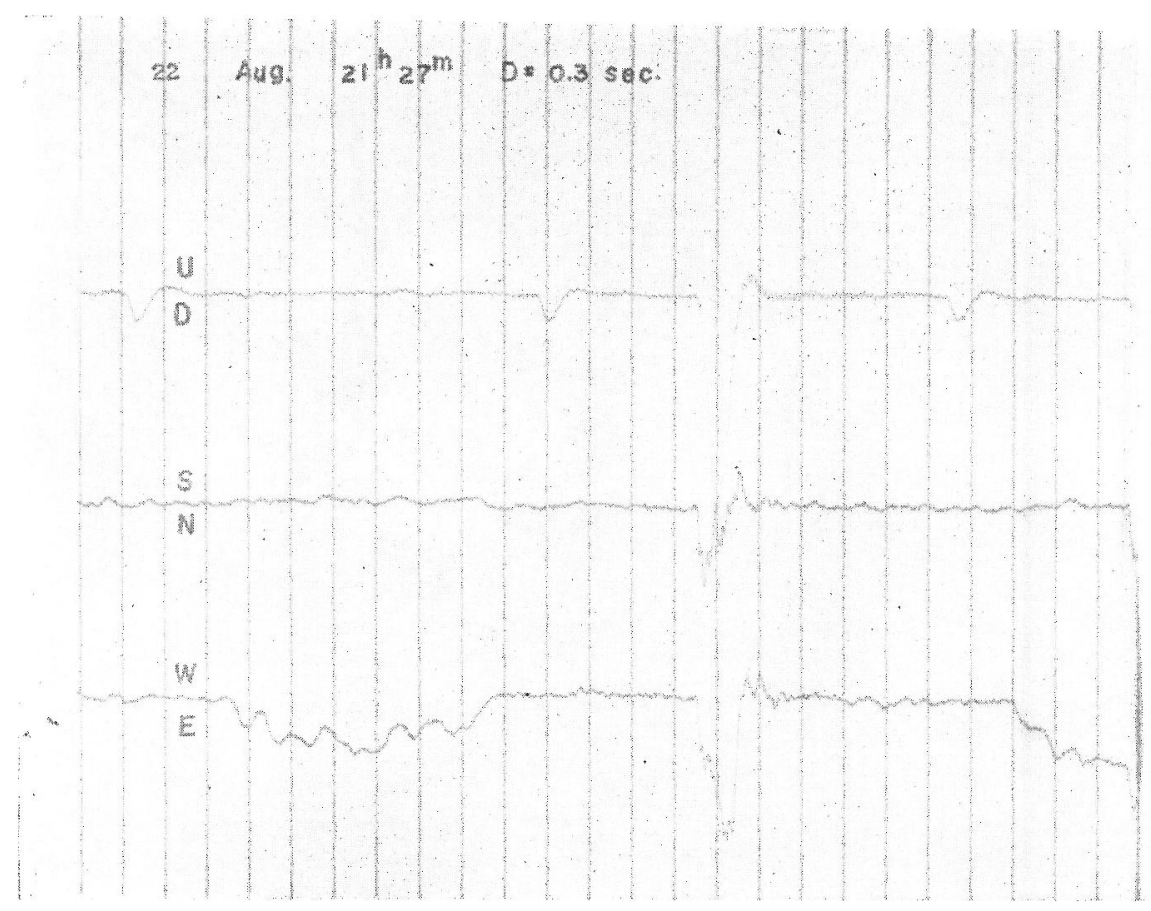

Fig. 3. An example of traces of back ground noises or electric circuit noises recorded at Takao station. (Time markes: every $0.1 \mathrm{sec}$ )

分布である。黑く败りつぶした部分は，

高尾 1 点の矢で記録されたものの数で

ある。乙礼によると，継続時間1秒以

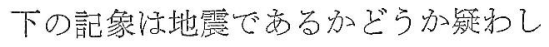
いものがほとえど卓占めるが，2秒以

上㷧马と，少なくとも 2 点以上の記 録少得られ，自然地震で京ると洘えて も差し卖えないようで要る。

このように桠めて小規䄑夵地震の判定

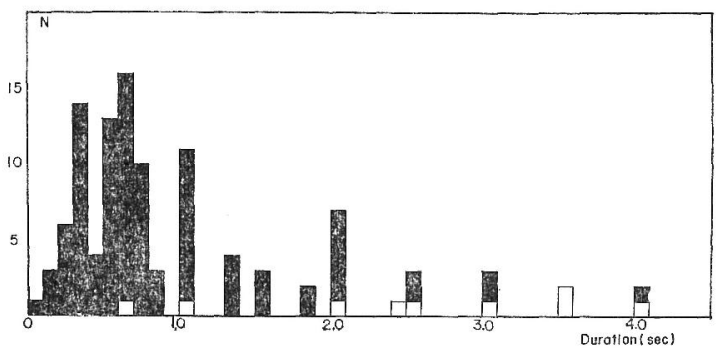

Fig. 4. Frequency distribution of duration times of shocks recorded at Takao station. The black portions denote the number of shocks recorded at Takao station and not at the other stations.

方法が磪立さ机ていない現在，比較的規模が大きく，少なくとも2点以上で同時に記録された

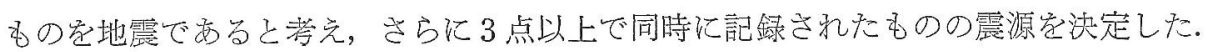

\section{§4. 地震の発生頻度}

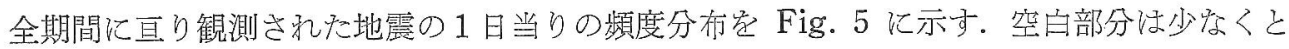
も 2 個所の観測点で記録されたもので，地震々考光て差し支えないものの数である，黒く好り 
つぶした部分は前述のように非常に小さい地 震や，地震と誤認された noises を含んでい る.この図でまず注目されることは，7月 29〜30 日に1つの極大がみられることであ る.この極大部分のほとんどの地震は古川で 観測されたものである。これは，その附近で 短時間継続した群発地震であるか，または大 きい地震に附随した余震群ではないかと思わ れるので，各観測点の読取り值をもとにし て，この期間の P-S 時間の度数分布をつく つてみた. Fig. 6 は古川のものであり, P$\mathrm{S}$ 時間 $4 \sim 5$ 秒に顕著な極大がある. 他の観 測点の結果は地震の数が少なくて，このよう な明瞭な極大は表われていないＦig１亿 示したように古川は large network の北東 の端に位置し, この地震群は他の隣接した観 測点でほとんど記録されていないことを考慮 すると， large network の外側で群発した ものであると考光らる。

Table 1 に示すように, large network の連続観測が本格的に始まつたのは 7 月 30 日からであり，それ以前は準倩段階であつ た。また Neo Valley network の夜間観測 は 8 月 14 日から始められた。 こういう事 情を考慮して，1日当りの地震数の変化を久 ると，観測点の数によつて地震が数がどう変 化するかがタられる。すなわち前述の古川の

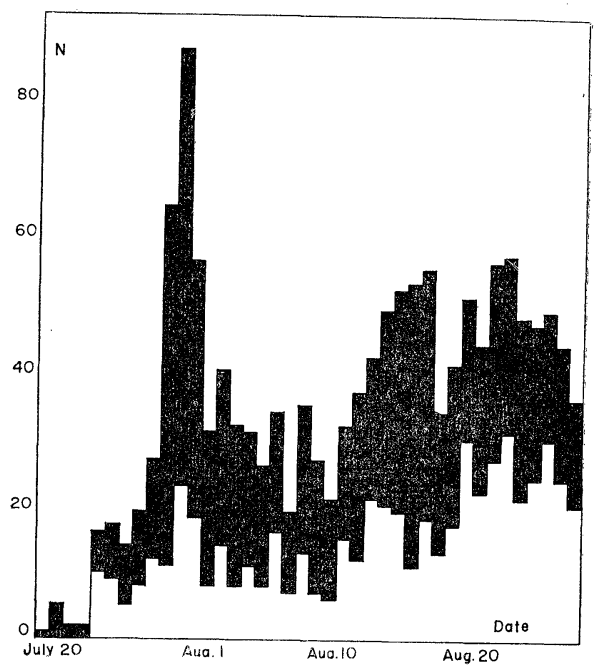

Fig. 5. Change of number of shocks in a day. The white portions correspond to the number of shocks registered at 2 stations or more.

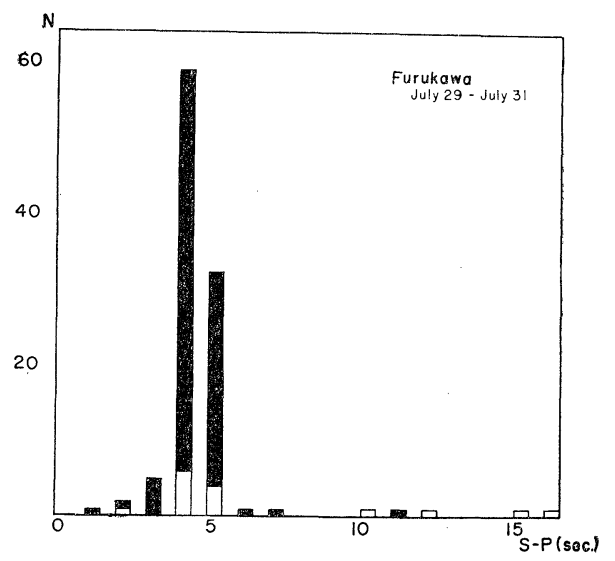

Fig. 6. Distribution of P-S intervals of shocks recorded at Furukawa station. The black portions denote the number of shocks recorded at Furukawa only.

みで観測された地震を除き，さらに Neo Valley network の夜間の高感度観測により観測さ れる地震数の急激な増加を考慮して Fig. 5 をみると，全期間を通じて 1 日当り発生する地震 数の変化はあまりないと考えてもよいようである.

次に観測点の数の夕でなく, いかに地震計の感度によつて観測される地震数が变化するかを 
示したのが Fig. 7 である.これは Neo Valley network の観測期間中 ( 8 月 15 28 日）の地震の総数を発生時刻によつて示 したものである，これによると，夜間の高 感度観測実施中は屋間に比較して，1時間 当りの地震数が約 3 倍に増加している. ま た仮にこの程度の高感度連続観測がこの地 域で行なわれたとすれば，マグニチュード 0 以下の極微小地震を含めて 1 日当り平均, 約 50 個の地震が記録されることがわかる.

\section{§5. 震央分布}

5 個以上の観測值をるつ地震については, $\mathrm{P}$ 波の arrival time から, 均質, 半無限 のモデルを仮定し, 発震時, 平均速度およ び震源位置を決定した。 また，少なくとも

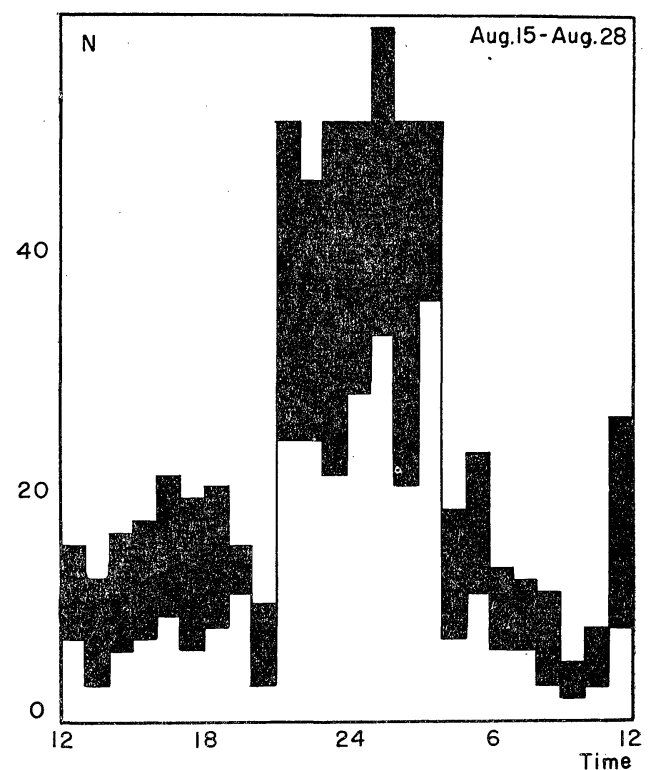

Fig. 7. Change of number of shocks in an hour. The white portions denote the number of shocks recorded at 2 stations or more.

3 個以上の P-S 時間が得られた地震については, 別に図式解法で震央を決定した。震央はこ れらの方法でかなり異る場合がある。それぞれの方法で求まつた震央のくいちがいの度数分布 をつくつてみると，そのちがいが $20 \mathrm{~km}$ 以下で決められるものは総数の約 $60 \%$ \%でるが, 二三の地震は $80 \mathrm{~km}$ にも及んでいる. このように，震央決定の精度が極めて不十分である場 合がある. P-S 時間を用い, 大森係数 $\mathrm{K}$ 学仮定して震央学求めると，多少の誤差が含まれる ことは避けられない。しかしKの值を適当にとつた場合, 非常に大きいあやまりを checkす ることができる。一方 $\mathrm{P}$ 波の arrival time を用いる場合, 使用し得る観測值が 5 個に比較 して十分多くなければ，ただ 1 個の観測值でも大きな誤差を含めば，十分な精度で震源が求め られない。このような事情を考慮して，P-S 時間の観測值が少なくとも 3 個以上あり，図式 解法で震央が比較的精度よく決つたものを Fig. 8 の黒丸で示してある. また P-S 時間では 精度よく決まらなかつたものおよび P-S 時間の観測值がなく $\mathrm{P}$ 波 arrival time で決めた地 震を白丸で示した。な観測網のひろがりおよび震央決定の精度を考えて，Fig. 8 に示した 範囲の地震に制限した.

このようにして求めた震央分布が観測点配置の非一様性に影響されていることは明らかであ る. 特に根尾谷周辺では高感度観測が行なわれているので, 一見この附近で地震が多いように 


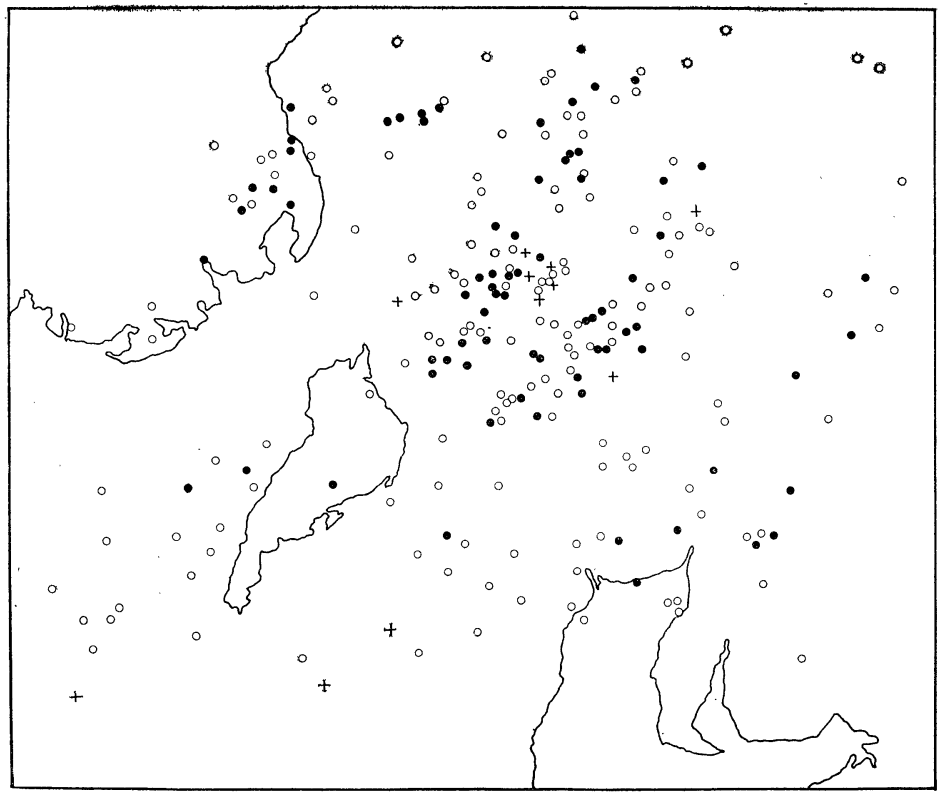

Fig. 8. Distribution of epicenters. The solid circles correspond to the locations of earthquakes determined by use of $\mathrm{P}-\mathrm{S}$ intervals with considerable accuracy.

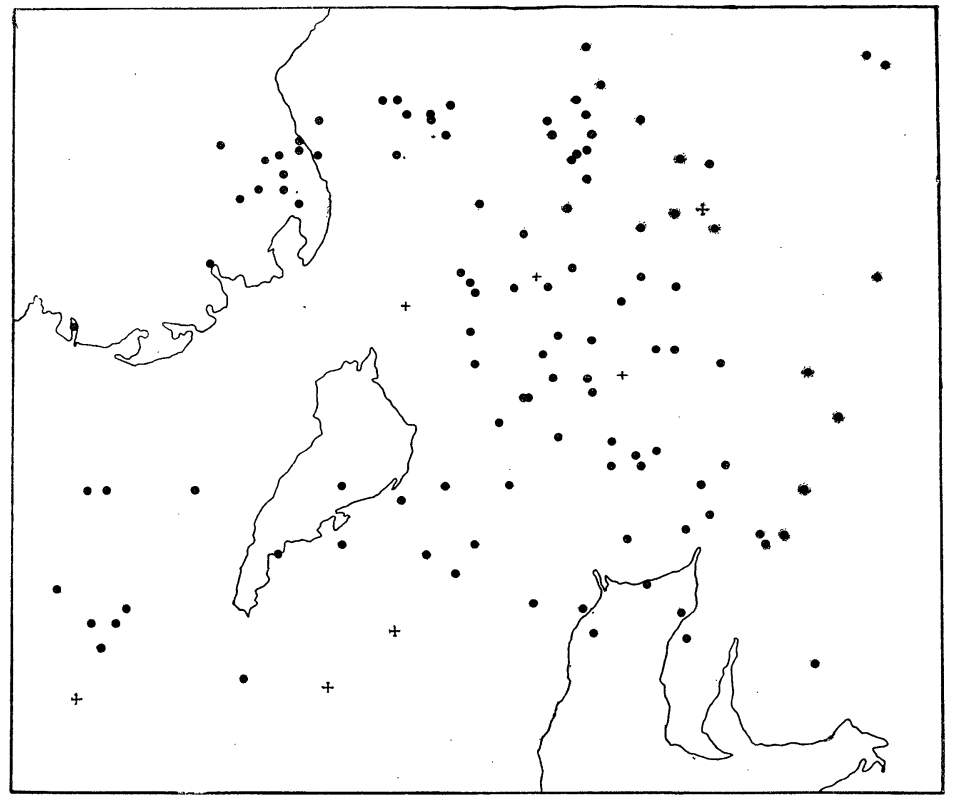

Fig. 9. Distribution of epicenters determined from both $\mathrm{P}$ wave arrival times and P-S intervals obtained at 8 stations (large network) and at Kôdoko station (Neo Valley network). 
みえる.この影響をとり除いてみるために, Neo Valley network の5観測点のうちそのほ ぼ中心にある神所以外すべて無視して決めた震央分布をつくつてみると Fig. 9 のようにな る.したがつてての観測網で決められた地震は前述のマグニチュード 0 以下の極微小地震では なく，マグニチュード 0 以上の比較的大きい地震が渒とんどであると考えられる.

Fig. 8 および Fig. 9 の両図から共通して注目されることは，特に観測点の配置に影響さ れないで，地震の発生しない空白部分がかなり明瞭にみられることである．例えば琵琶湖の北 側，郡上八幡の東側などに特に顕著に表われている.このことは換言すれば，地震の活動度が 地域によつてかなりの相異があるということである. Fig. 8 に特に明瞭にみられるように， このような微小な地震についてもほぼ北東から南西にわたるいくつかの地震帯が形成され, 互 いにほとえど平行に走つている.このことは，大規模な地震带および地体構造に関連して非常 に興味ある問題である.

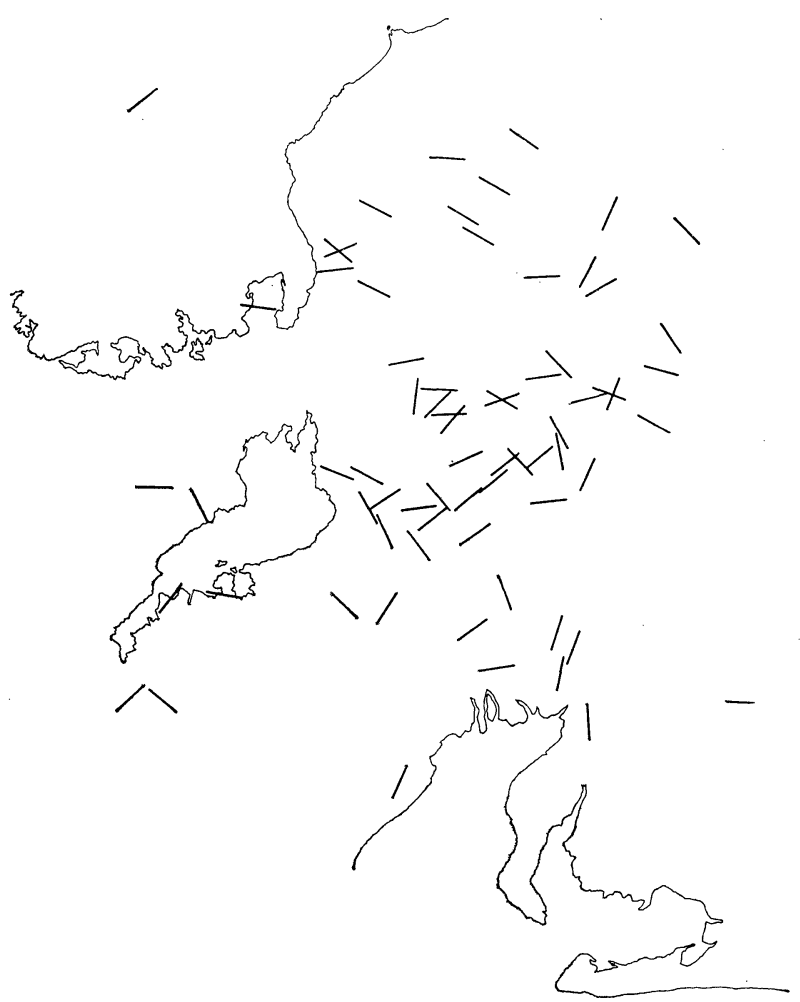

Fig. 10. Directions of the horizontal components of the maximum pressures determined under an assumption of the quadrant type pattern of initial $\mathrm{P}$ waves. 


\section{$\S 6$. 微小地震の発震機構}

微小地震の発震機構として, 四象限モデルを考え, ある観測点で初動が Up なら震源におけ るその観測点の方向の力は引きで, Down なら震源におけるその方向の力は押しであり，乙 の押し引きの方向は震源において直交すると仅定するにこのようにして決めた主圧力の方向は 震源をとりまく観測点の配置によつては非常に大きな誤差を含む括それがある。したがつて， 押し引きの方向がはつきり決まらないものはすべて除外し比較的よく決まつたものだけを Fig. 10 に示した，あまり明膫ではないが，全体として主王力の方向が $\mathrm{E}-\mathrm{W}$ 方向の地震が多 いようである。しかし琵琶湖の北東から根尾谷にかけての地域では，この傾向がかなり乱れて おり，主圧力の方向が同じ地域でほぼ直交する地震がいくつかみられることは注目に価する.

この主圧力の方向は $\mathrm{P}$ 波の方向のみならず $\mathrm{P}$ 波振幅分布および $\mathrm{S}$ 波の分布も同時に考慮し て，精度の向上をはかるべきであり，またここで仮定した四象限モデルにも問題が残されてい る.したがつてさらに立入つた議論は，将来の研究に俟たねばならないと思う。

\section{§7. おわりに}

極微小地震研究グループが結成され，今回が第 1 回目の共同観測である.とのグループの大 きな研究目標の 1 つは, 微小な地震の活動状況を調べ, 破壊的地震の発生との関係を調査, 研 究することであつた。またこのような微小な地震の最も合理的な観測方法の研究も大きな課題 であつた。

微小な地震を観測して，小さい領域の seismicity を研究するには，それに相応した密な観 測網が必要であることはいうまでもない，今回の共同観測のうちでも，特に根尾谷周辺の夜間 の高感度観測はマグニチュド 0 以下の極微小地震を含めて，1時間当り約 2 個の地震を記録す るととができた。一般に地震計の最高感度は back ground noise とのかね合いで決められ ることであるが，この程度の高感度観測が routine work として行なわれるならば，非常に 短期間の観測で，十分多量な資料が得られるはずである。このととは seismicity およびそれ に附随した多くの研究に明るい見透しを与え，このような観測網の整備がまたれる.

今回の共同観測はこの種の観測の最初の試みであつた。したがつて, 観測計器, 観測方法, 観測点の配置などにまだ多くの問題が残されている．これらの諸問題は，今後くわしく研究さ れ，最も合理的な観測方法および資料の解析方法が確立されるであろう.

なお，この観測は文部省科学研究費によつて行なわれたものである. 